
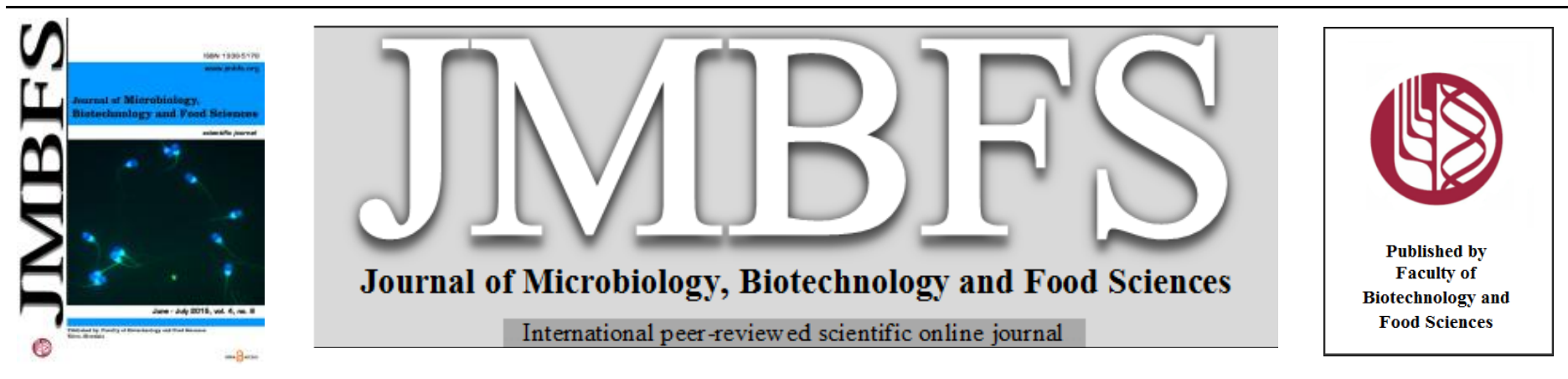

\title{
OPTIMIZATION OF NUTRITIONAL AND CULTURE CONDITIONS FOR IMPROVED PROTEASE PRODUCTION BY ASPERGILLUS NIDULANS AND ASPERGILLUS FLAVUS
}

\section{J. Joel Gnanadoss* and S. Kanchana Devi}

\section{Address(es):}

Microbial and Environmental Biotechnology Research Centre, Department of Plant Biology and Biotechnology, Loyola College (Autonomous), Chennai - 600034.

*Corresponding author: joelgna@gmail.com

doi: 10.15414/jmbfs.2015.4.6.518-523

ARTICLE INFO

Received 29.11. 2014

Revised 4. 2. 2015

Accepted 1. 4. 2015

Published 1. 6. 2015

Regular article

OPEN $\partial$ ACCESS

\begin{abstract}
Aspergillus sp. is considered to be a good source of protease. Medium optimization is essential for each isolate in order to maximise the protease production. In the present study, different media were evaluated for maximising protease biosynthesis under submerged fermentation (SmF) using A. nidulans LCJ249 and A. flavus LCJ253. Among the six media tested, Medium 6 was found to be the best medium for maximum protease production in both A. nidulans LCJ249 $(1178.0 \mathrm{U} / \mathrm{mL})$ and A. flavus LCJ253 $(950.6 \mathrm{U} / \mathrm{mL})$. Effect of essential nutrient parameters like carbon, nitrogen and casein and other culture conditions such as incubation time, inoculum size, $\mathrm{pH}$ and shaking and static conditions were evaluated by the conventional one factor at a time approach. In the case of A. nidulans LCJ249, a medium containing $20 \mathrm{~g} / \mathrm{L}$ glucose, $15 \mathrm{~g} / \mathrm{L}$ malt extract, $5 \mathrm{~g} / \mathrm{L}$ casein, initial medium pH of 7 and inoculum size of $30 \mathrm{mg} / \mathrm{L}$ favoured maximum protease production. Similarly, in A. flavus LCJ253, a medium containing $20 \mathrm{~g} / \mathrm{L}$ starch, $20 \mathrm{~g} / \mathrm{L}$ peptone, $15 \mathrm{~g} / \mathrm{L}$ casein, initial medium $\mathrm{pH}$ of 7 and inoculum size of $10 \mathrm{mg} / \mathrm{L}$ favoured maximum protease production. In both the cultures, protease production was higher under shaking condition than in static conditions. The study showed that the optimised medium with optimal conditions enhanced protease production when compared to the original medium.
\end{abstract}

Keywords: Proteases, submerged fermentation, Aspergillus, medium optimization

\section{INTRODUCTION}

Proteases hydrolyse a wide variety of proteins (Genckal and Tari, 2006). Proteases find application in detergent, meat, protein, brewing, photographic, leather and dairy industries (Anwar and Saleemuddin, 1998). Proteases are classified into six prominent groups such as serine proteases, cysteine (or) sulphydral proteases, aspartic proteases, metalloproteases, threonine proteases and glutamic acid proteases (Son and Kim, 2002) and based on their optimum $\mathrm{pH}$ activity they are classified as acid, neutral, and alkaline proteases (Asoodeh and Abadi, 2012). Among the microorganisms used for the protease production, filamentous fungi are extensively exploited because of their capacity to grow on many substrates and produce various enzymes (Lekha and Lonsane, 1994).

Submerged fermentation $(\mathrm{SmF})$ involves the production of enzymes in liquid medium. In SmF, scale-up from laboratory level to industry is simple, with parameters being more easily monitored and controlled (Rao et al., 1998). Submerged fermentation is preferred for the production of proteases due to steady protease production, definite medium and easier downstream processing (Sandhyaa et al., 2005). Several physical and nutritional factors influence the production of protease and hence optimization of these factors is essential to improve the yield and make the process cost-effective (Rani et al., 2012). Optimization by conventional methods (one factor at a time) is done by varying one particular parameter at a time while keeping the other parameters constant (Wu and Hang, 2000).This method helps to assess the importance of a specific parameter on the enzyme production.

The objective of our work was to optimize nutritional and physical conditions for enhancing protease production by A. nidulans LCJ249 and A. flavus LCJ253 using 'one factor at a time' method under submerged fermentation and scaling up of the production using the modified conditions.

\section{MATERIAL AND METHODS}

Culture and maintenance

A. nidulans LCJ249 and A. flavus LCJ253 used for this study were isolated from soil and leaf litters collected from Loyola College Campus, Chennai. The above cultures were maintained on potato dextrose agar plates at $4{ }^{\circ} \mathrm{C}$ and sub-cultured periodically.

\section{Effect of nutritional conditions}

\section{Selection of liquid medium for protease production}

Production of protease by submerged fermentation was studied in six different basal medium. Medium 1 (Gradisar et al., 2005) g/L: Glucose - $1, \mathrm{KH}_{2} \mathrm{PO}_{4}-1$, $\mathrm{MgSO}_{4}-0.2, \mathrm{CaCl}_{2}-0.2, \mathrm{NaCl}-0.2 ;$ Medium 2 (Srinubabu et al., 2007) g/L: Malt Extract - 1, Glucose - 6, Yeast Extract - 1, Peptone - 2, $\mathrm{K}_{2} \mathrm{HPO}_{4}-0.5$, $\mathrm{MgSO}_{4}-0.5, \mathrm{FeSO}_{4}-0.01, \mathrm{pH}-8.3$; Medium 3 (Tsuchiya et al., 1992) g/L: Maltose - 1, Yeast Extract - 0.04, $\mathrm{KH}_{2} \mathrm{PO}_{4}-0.5, \mathrm{NaCl}-0.2, \mathrm{pH}-8.5$; Medium 4 (Saravanakumar et al., 2010) g/L: Malt Extract - 20, Fructose - 5, Thio Urea $0.005, \mathrm{KH}_{2} \mathrm{PO}_{4}-1, \mathrm{KCl}-1, \mathrm{FeSO}_{4} \cdot 7 \mathrm{H}_{2} \mathrm{O}-0.02, \mathrm{MgSO}_{4} .7 \mathrm{H}_{2} \mathrm{O}-0.5, \mathrm{pH}-8$; Medium 5 (Charles et al., 2008) g/L: Sucrose - 30, $\mathrm{KCl}-0.5, \mathrm{FeSO}_{4}-0.01$, $\mathrm{MgSO}_{4}-0.5, \mathrm{~K}_{2} \mathrm{HPO}_{4}-1, \mathrm{NaNO}_{3}-2, \mathrm{pH}-8$; Medium 6 (Namasivayam et al., 2010) g/L: Yeast Extract - 5, Peptone - 5, Glucose - 10, Casein - 20, pH - 7.

About $100 \mathrm{~mL}$ of each medium was dispensed into $250 \mathrm{~mL}$ conical flask and autoclaved at $121^{\circ} \mathrm{C}$ for $15 \mathrm{~min}$. A pinch of nalidixic acid was added to avoid bacterial contamination. Under sterile condition, two mycelial discs from a fully grown fungal plate were inoculated into the conical flask. The flasks were incubated on an orbital rotary shaker set to $30{ }^{\circ} \mathrm{C}$ and $120 \mathrm{rpm}$. Aliquots of the culture filtrate were collected for determination of extracellular protease activity.

\section{Optimization of essential nutrients}

Various nutritional parameters for protease production were optimized by the "one factor at a time" method which involves changing only one independent variable, while fixing the others at certain levels in the original medium. Each subsequent factor was examined after taking into account the previously optimized factors.

The effect of carbon sources on protease production was studied by supplementing the media with separately with glucose, sucrose, galactose, maltose, starch and lactose at a concentration of $10 \mathrm{~g} / \mathrm{L}$. Original medium served as a control. The most suitable concentration of carbon source for A. nidulans 
LCJ249 and A. flavus LCJ253 was further determined using the most suitable carbon source in the range of 5 to $30 \mathrm{~g} / \mathrm{L}$.

The effect of nitrogen source on protease production was studied by supplementing the medium with three organic nitrogen (malt extract, peptone, and yeast extract) and three inorganic nitrogen (ammonium sulphate, ammonium chloride and ammonium nitrate) sources. These nitrogen sources replaced the original nitrogen source (yeast extract, peptone and casein) available in the medium. The original medium served as control. The optimum concentration of the suitable nitrogen source for protease production by A. nidulans LCJ249 and A. flavus LCJ253 was carried out by varying the concentrations of the suitable nitrogen source in the range of 5 to $30 \mathrm{~g} / \mathrm{L}$.

The effect of the inducer casein on protease production by A. nidulans LCJ249 and A. flavus LCJ253 was evaluated. The effect of different concentrations of casein ranging from 5 to $30 \mathrm{~g} / \mathrm{L}$ was also studied.

\section{Optimization of culture conditions}

The optimal time of incubation for maximum protease production by $A$. nidulans LCJ249 and A. flavus LCJ253 was determined by incubating the flasks containing the medium for a period of 16 days. Aliquots of the culture filtrate were drawn every 2 days and used for the determination of extracellular protease activity. The biomass was also simultaneously harvested and used for the determination of fresh weight and dry weight.

The effect of different inoculum size on protease production by A. nidulans LCJ249 and A. flavus LCJ253 was evaluated using various inoculum sizes ranging from 10 to $60 \mathrm{mg} / 100 \mathrm{~mL}$. Mycelial discs $(6 \mathrm{~mm})$ were inoculated into the conical flask containing culture medium. The amount of mycelium on agar plug was determined, based on which inoculum size was calculated. The protease activity was determined at the end of the study period.

The effect of initial $\mathrm{pH}$ of the medium on protease production by A. nidulans LCJ249 and A. flavus LCJ253 was studied under different $\mathrm{pH}$ range ranging from 4 to 9 . The $\mathrm{pH}$ of the production medium was adjusted by adding $1 \mathrm{~N}$ $\mathrm{NaOH}$ and $\mathrm{HCl}$.

The effect of static and shaking condition on protease production was studied by incubating under static and shaking condition $(120 \mathrm{rpm})$ at $30^{\circ} \mathrm{C}$.

\section{Protease production in original and optimised medium}

Protease production by A. nidulans LCJ249 and A. flavus LCJ253 in the optimised and original medium (Namasivayam et al., 2010) was compared. The modified medium for A. nidulans LCJ249 contained the following components (g/L): Malt Extract - 15, Glucose - 20, Casein - 5 and the modified media for $A$. flavus LCJ253 contained (g/L): Peptone - 20, Starch - 20, Casein - 15. Fermentation was carried out in Erlenmeyer flasks (1L) containing $500 \mathrm{~mL}$ of the modified production medium. The medium containing flasks were inoculated with the mycelia discs. The flasks were incubated at room temperature for 1 week in a rotary shaker at $120 \mathrm{rpm} .10 \mathrm{~mL}$ of the culture filtrate was drawn on the peak day and centrifuged at $3600 \mathrm{rpm}$ for $10 \mathrm{~min}$. The supernatant was used as a crude enzyme for protease activity.

\section{Protease assay}

Protease activity was determined spectrophotometrically using casein as the substrate. A mixture of $500 \mu \mathrm{L}$ of casein $(0.5 \% \mathrm{w} / \mathrm{v}), 300 \mu \mathrm{L}$ of $0.2 \mathrm{M}$ phosphate buffer $(\mathrm{pH} 7)$ and $200 \mu \mathrm{L}$ crude enzyme extract were incubated at room temperature $37{ }^{\circ} \mathrm{C}$ for 10 minutes. After 10 minutes, the enzyme reaction was terminated by the addition of $1 \mathrm{~mL}$ of $5 \%(\mathrm{w} / \mathrm{v})$ trichloroacetic acid (TCA). The reaction mixture was then centrifuged at $10,000 \mathrm{rpm}$ for 15 minutes to separate the unreacted casein. To $1 \mathrm{~mL}$ of the supernatant, $5 \mathrm{~mL}$ of $0.4 \mathrm{M}$ $\mathrm{Na}_{2} \mathrm{CO}_{3}$ and $1 \mathrm{~mL}$ of 3 -fold diluted Folin Ciocalteu's reagent were added. The resulting solution was incubated in the dark for 30 minutes at room temperature and absorbance was measured at $660 \mathrm{~nm}$ (Lowry $\boldsymbol{e t}$ al., 1951).

Enzyme activity (1 Unit) was defined as the amount of enzyme liberating one $\mu /$ mole of tyrosine $/ \mathrm{mL} / \mathrm{min}$ under the defined conditions.

$$
(\mu / \text { mole tyrosine equivalents released }) \times 7
$$

Units/ml Enzyme activity =

$$
0.2 \times 4 \times 10
$$

$7 \quad=$ Total volume (in millilitres) of assay $10=$ Time of assay (in minutes) as per the Unit definition $0.2=$ Volume of Enzyme (in millilitres) of enzyme used $4=$ Volume (in millilitres) used in Colorimetric Determination (Sigma Aldrich method).

\section{Protein assay}

Protein content of the extract was estimated following the method described by Lowry et al. (1951) using bovine serum albumin as the standard.

\section{Statistical analysis}

Each parameter was analyzed with three replicates and a standard deviation (SD) was calculated and data are expressed \pm SD of three replication.

\section{RESULTS}

\section{Selection of liquid medium for protease production}

The protease production was significantly different in all the 6 media tested. Among the six media studied, Medium 6 favoured maximum protease production in both A. nidulans LCJ249 and A. flavus LCJ253 as shown in Figure 1. In Medium 6, a maximum protease activity of $988.4(\mathrm{U} / \mathrm{mL})$ and 950.6 $(\mathrm{U} / \mathrm{mL})$ was recorded in A. nidulans LCJ249 and A. flavus LCJ253 on the $6^{\text {th }}$ day of incubation. Results also proved that Medium 1 did not favour protease production in both the cultures.

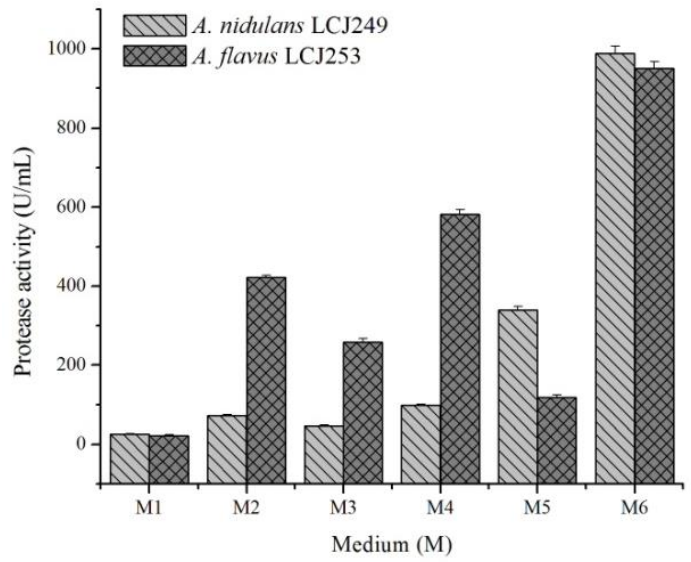

Figure 1 Influence of different medium compositions on the protease production by A. nidulans LCJ249 and A. flavus LCJ253

\section{Optimization of essential nutrients}

To optimize the most suitable carbon source for protease production by $A$. nidulans LCJ249 and A. flavus LCJ253, experiments were carried out using glucose, sucrose, galactose, maltose, starch and lactose in Medium 6 and the results are presented in Table 1 . The result showed that glucose enhanced significantly higher protease production $(1183.0 \mathrm{U} / \mathrm{mL})$ in A. nidulans LCJ249, when compared to other carbon sources. Maltose also moderately favoured protease production in A. nidulans LCJ249. In the case of A. flavus LCJ253, the liquid medium containing starch as the carbon sources favoured maximum amount of protease $(1474 \mathrm{U} / \mathrm{mL})$ and the next suitable carbon source was lactose.

The suitable nitrogen source for the protease production by A. nidulans LCJ249 and A. flavus LCJ253 was studied using organic (malt extract, peptone and yeast extract) and inorganic nitrogen sources (ammonium sulphate, ammonium chloride and ammonium nitrate) and the results are presented in Table 1 . The results showed that in general organic nitrogen favoured better growth high protease production when compared to inorganic nitrogen sources. In the case of A. nidulans LCJ249, maximum protease production of $1134.0 \mathrm{U} / \mathrm{mL}$ was recorded in the medium amended with malt extract on the $6^{\text {th }}$ day of culture. Whereas in A. flavus LCJ253, the medium amended with peptone favoured a maximum protease production $1129.8 \mathrm{U} / \mathrm{mL}$ on the $6^{\text {th }}$ day. In all the experiments, protease activity was observed from the first day of inoculation and peak activity was observed on the $6^{\text {th }}$ day and declined thereafter.

The effect of different concentrations of glucose (most suitable carbon source) was studied to ascertain the most suitable concentration for protease production by A. nidulans LCJ249 and the results are shown in Table 2. Results showed that $20 \mathrm{~g} / \mathrm{L}$ of glucose significantly increased the yield of protease $(833 \mathrm{U} / \mathrm{mL})$ when compared to other concentrations. It was initially observed that the production of protease increased with increase in the concentration of glucose but declined when the concentration was increased beyond $20 \mathrm{~g} / \mathrm{L}$. The effect of different concentration of malt extract (suitable nitrogen source) on the protease production by A. nidulans LCJ249 was studied and it was found that malt extract concentration of $15 \mathrm{~g} / \mathrm{L}$ was ideal for maximum protease activity of 1212.4 $\mathrm{U} / \mathrm{mL}$ (Table 2). 
Table 1 Influence of essential nutrients on the protease production by $A$. nidulans LCJ249 and A. flavus LCJ253 on the sixth day.

\begin{tabular}{lll}
\hline Nutrients & A. nidulans LCJ249 & A. flavus LCJ253 \\
\hline Carbon Sources & \multicolumn{2}{c}{ Protease activity $(\mathbf{U}$ /mL) } \\
\hline Glucose & $\mathbf{1 1 8 3 . 0} \pm \mathbf{3 5 . 2}$ & $504.0 \pm 14.0$ \\
Galactose & $742.0 \pm 22.1$ & $1076.6 \pm 33.4$ \\
Lactose & $651.0 \pm 15.2$ & $1376.2 \pm 32.8$ \\
Maltose & $786.8 \pm 20.8$ & $883.4 \pm 27.6$ \\
Starch & $683.2 \pm 18.7$ & $\mathbf{1 4 7 4 . 2} \pm 31.3$ \\
Sucrose & $620.2 \pm 16.9$ & $784.0 \pm 15.5$ \\
\hline Nitrogen Sources & & \\
\hline Yeast extract & $819.0 \pm 25.4$ & $868.0 \pm 30.2$ \\
Peptone & $841.4 \pm 28.2$ & $\mathbf{1 1 2 9 . 8} \pm 31.1$ \\
Malt extract & $\mathbf{1 1 3 4 . 0} \pm 33.5$ & $805.0 \pm 14.9$ \\
Ammonium nitrate & $834.4 \pm 22.0$ & $302.4 \pm 10.5$ \\
Ammonium chloride & $684.6 \pm 16.8$ & $488.6 \pm 12.2$ \\
Ammonium sulphate & $459.2 \pm 16.7$ & $141.4 \pm 8.1$ \\
\hline
\end{tabular}

Table 2 Influence of various concentrations of glucose and malt extract on the protease production by A. nidulans LCJ 249 on the sixth day.

A .nidulans LCJ249

\begin{tabular}{lll}
\multirow{2}{*}{ Concentration $(\mathbf{g} / \mathbf{L})$} & \multicolumn{2}{l}{$\boldsymbol{A}$.nidulans LCJ249 } \\
\cline { 2 - 3 } & \multicolumn{2}{l}{ Protease activity $(\mathbf{U} / \mathbf{m L})$} \\
\cline { 2 - 3 } & Glucose & Malt extract \\
\hline Control & $546.0 \pm 20.2$ & $884.8 \pm 22.5$ \\
5 & $397.6 \pm 10.1$ & $701.4 \pm 20.8$ \\
10 & $445.2 \pm 15.6$ & $964.6 \pm 33.6$ \\
15 & $422.8 \pm 12.8$ & $\mathbf{1 2 1 2 . 4} \pm 40.1$ \\
20 & $\mathbf{8 3 3 . 0} \pm 23.1$ & $1071.0 \pm 38.4$ \\
25 & $509.6 \pm 15.6$ & $870.8 \pm 20.9$ \\
30 & $656.6 \pm 13.8$ & $981.4 \pm 22.7$ \\
\hline
\end{tabular}

The effect of different concentrations of starch on the protease production by $A$. flavus $\mathrm{LCJ} 253$ showed that $20 \mathrm{~g} / \mathrm{L}$ starch resulted in a higher yield of protease of $1393 \mathrm{U} / \mathrm{mL}$ (Table 3). It was observed that initially the production of protease increased with increase in the concentration of starch but declined when the concentration was increased after $20 \mathrm{~g} / \mathrm{L}$. In A. flavus LCJ253, peptone concentration of $30 \mathrm{~g} / \mathrm{L}$ enhanced a maximum protease activity of $2594 \mathrm{U} / \mathrm{mL}$ closely followed by $20 \mathrm{~g} / \mathrm{L}$ peptone $(2528 \mathrm{U} / \mathrm{mL})$. Taking into consideration the cost factor, $20 \mathrm{~g} / \mathrm{L}$ peptone was chosen as optimum for the production of protease in the case of A. flavus LCJ253 (Table 3).

Table 3 Influence of various concentrations of starch and peptone on the protease production by A. flavus LCJ253 on the sixth day.

\begin{tabular}{lll}
\hline & \multicolumn{2}{l}{ A.flavus LCJ253 } \\
\cline { 2 - 3 } Concentration (g/L) & Starch & Peptone \\
\hline Control & $842.6 \pm 20.1$ & $820.4 \pm 22.5$ \\
5 & $641.2 \pm 15.2$ & $1334.2 \pm 34.6$ \\
10 & $721.0 \pm 18.4$ & $1274.0 \pm 33.8$ \\
15 & $826.0 \pm 22.5$ & $1719.2 \pm 39.4$ \\
20 & $\mathbf{1 3 9 3 . 0} \pm 30.8$ & $2528.4 \pm 44.1$ \\
25 & $725.2 \pm 14.3$ & $2279.6 \pm 31.5$ \\
30 & $1145.2 \pm 28.6$ & $\mathbf{2 5 9 4 . 2} \pm 42.7$ \\
\hline
\end{tabular}

The effect of different concentrations of casein (inducer) on protease activity in both the cultures was studied. In A. nidulans LCJ249, $15 \mathrm{~g} / \mathrm{L}$ casein enhanced maximum protease activity $(1346 \mathrm{U} / \mathrm{mL})$ as shown in Figure 2. Likewise, in $A$ flavus $\mathrm{LCJ} 253,15 \mathrm{~g} / \mathrm{L}$ casein induced maximum protease production (1489 $\mathrm{U} / \mathrm{mL}$ ). The production of protease increased with increase in the concentration of casein but declined when its concentration exceeded $20 \mathrm{~g} / \mathrm{L}$.

\section{Optimization of culture conditions}

The protease activity was recorded every 2 days in order to determine the optimum incubation period for maximum production of protease. In both the isolates (A. nidulans LCJ249 and A. flavus LCJ253), maximum protease production was observed on the $6^{\text {th }}$ day of incubation at room temperature. In $A$. nidulans LCJ249, a protease activity of $1261.4 \mathrm{U} / \mathrm{mL}$ and a protease activity of $1580.4 \mathrm{U} / \mathrm{mL}$ in A. flavus LCJ253 were observed on the $6^{\text {th }}$ day. Prolonged incubation period decreased the enzyme activity (Table 4).

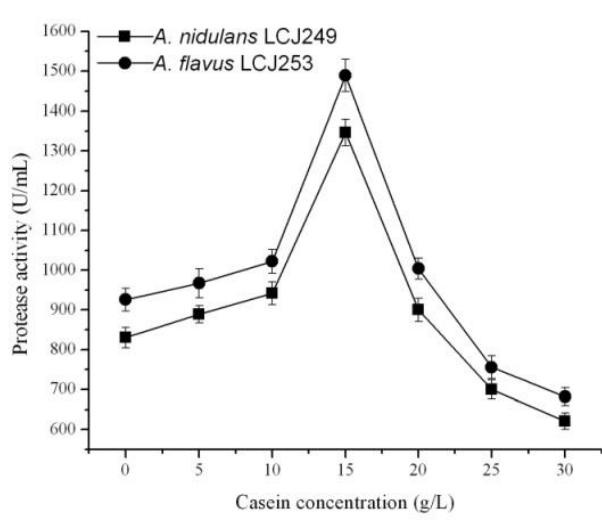

Figure 2 Influence of casein concentration on the protease production by $A$. nidulans LCJ249 and A. flavus LCJ253

Table 4 Influence of culture conditions on the protease production by $A$. nidulans LCJ249 and A. flavus LCJ253

\begin{tabular}{lll}
\hline \multirow{2}{*}{ Culture conditions } & A.nidulans $\mathbf{L C J 2 4 9}$ & A.flavus $\mathbf{L C J 2 5 3}$ \\
\cline { 2 - 3 } Incubation time (Days) & \multicolumn{2}{l}{ Protease activity $(\mathbf{U} / \mathbf{m L})$} \\
\hline 2 & $1009.4 \pm 38.1$ & $735.2 \pm 25.2$ \\
4 & $1117.2 \pm 42.5$ & $1404.0 \pm 40.6$ \\
6 & $\mathbf{1 2 6 1 . 4} \pm 40.6$ & $\mathbf{1 5 8 0 . 4} \pm 45.1$ \\
8 & $1012.2 \pm 38.1$ & $597.4 \pm 11.7$ \\
10 & $964.6 \pm 20.9$ & $526.2 \pm 10.8$ \\
\hline pH & \multicolumn{2}{l}{} \\
\hline 4 & $810.6 \pm 15.2$ & $1180.2 \pm 38.1$ \\
5 & $978.6 \pm 13.1$ & $1495.2 \pm 32.5$ \\
6 & $1153.6 \pm 33.4$ & $2080.4 \pm 41.2$ \\
7 & $\mathbf{1 2 8 9 . 4} \pm 38.1$ & $\mathbf{2 0 9 7 . 2} \pm 40.3$ \\
8 & $1096.2 \pm 29.5$ & $1908.2 \pm 30.7$ \\
9 & $960.4 \pm 26.1$ & $1930.6 \pm 30.2$ \\
\hline Inoculum size (mg) & & \\
\hline 10 & $841.4 . \pm 33.2$ & $\mathbf{2 2 2 3 . 2} \pm 40.8$ \\
20 & $950.6 \pm 36.4$ & $1402.8 \pm 35.1$ \\
30 & $\mathbf{1 2 5 8 . 0} \pm \mathbf{4 1 . 2}$ & $1397.2 \pm 33.0$ \\
40 & $1068.2 \pm 40.9$ & $1358.0 \pm 28.9$ \\
50 & $1118.6 \pm 43.6$ & $1170.4 \pm 22.1$ \\
60 & $1157.2 \pm 35.4$ & $1099.0 \pm 30.5$ \\
\hline Static and shaking conditions & \\
\hline Static & $1351.0 \pm 41.3$ & $\mathbf{2 0 5 9 . 4} \pm 60.2$ \\
Shaking & $\mathbf{2 2 6 2 . 4} \pm 54.9$ & \\
\hline
\end{tabular}

Time course experiments showed that the protease activity increased with increase in time and the peak protease activity was observed on the $6^{\text {th }}$ day. The protease activity decreased thereafter. The effect of initial $\mathrm{pH}$ (4 to 9) of the medium on protease shows that initial $\mathrm{pH}$ of 7 was the best $\mathrm{pH}$ for the production of protease by A. nidulans LCJ249 and A. flavus LCJ253. In A. nidulans LCJ249, a protease activity of $1289.4 \mathrm{U} / \mathrm{mL}$ and in A. flavus LCJ253, a protease activity of $2097.2 \mathrm{U} / \mathrm{mL}$ was observed at $\mathrm{pH} 7$ (Table 4). However, protease activity was present at all $\mathrm{pH}$ evaluated in this study. The effect of different inoculum size on protease production by A. nidulans LCJ249 and A. flavus LCJ253 was studied. In A. nidulans LCJ249, the maximum protease activity of $1258 \mathrm{U} / \mathrm{mL}$ was observed with addition of $30 \mathrm{mg}$ of inoculum size. Whereas in A. flavus LCJ253, the maximum protease production of $2223.2 \mathrm{U} / \mathrm{mL}$ was obtained with $10 \mathrm{mg}$ of inoculum size (Table 4 ). The culture medium became more viscous by increasing the inoculums size.

In A. nidulans LCJ249 when compared to the static condition, shaking condition favoured maximum protease production of $2262.4 \mathrm{U} / \mathrm{mL}$ on the $6^{\text {th }}$ day of incubation. In A. flavus LCJ253 also shaking condition favoured maximum protease production of $2059.4 \mathrm{U} / \mathrm{mL}$ on the $6^{\text {th }}$ day of incubation (Table 4 ).

\section{Protease production in original and optimised medium}

Protease production by A. nidulans LCJ249 and A. flavus LCJ253 in the original and the optimised medium was studied. In A. nidulans LCJ249, the modified medium showed a maximum protease activity $(1267.0 \mathrm{U} / \mathrm{mL})$ on the $6^{\text {th }}$ day when compared to the original medium $(961.8 \mathrm{U} / \mathrm{mL})$. Likewise, in A. flavus LCJ253, the protease production was $1583.4 \mathrm{U} / \mathrm{mL}$ in the modified medium when compared to the original medium where it was $679.0 \mathrm{U} / \mathrm{mL}$ (Figure 3). The results showed that the optimised medium enhanced the protease production in both the cultures. 


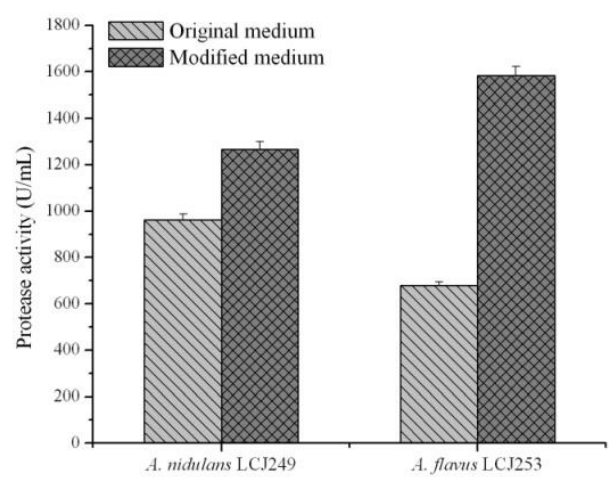

Figure 3 Protease production by A. nidulans LCJ249 and A. flavus LCJ253 in the original and optimised medium

\section{DISCUSSION}

Fungal proteases are produced extracellularly which make it easy to be recovered from the fermentation medium (Sandhya et al., 2005; Murthy and Naidu, 2010). Filamentous fungi also have the potential to grow under varying environmental conditions such as fermentation type, time, $\mathrm{pH}$, temperature and utilizing various sources of substrate as nutrients (Ikram-ul-haq et al., 2006). Proteases obtained from Aspergillus sp. have been declared to be safe. Aspergillus niger has been reported to produce proteases (Paranthaman $\boldsymbol{e t}$ al., 2009). Similarly, protease production has been reported in Aspergillus oryzae and Aspergillus fischeri (Murthy and Naidu, 2010; Saravanakumar et al., 2010). The optimization of medium components is carried out to maintain a balance between the various medium components and thus minimizes the amount of unutilized components at the end of the fermentation process (Kumara et al., 1999). Several researchers have reported different methods to optimize the production of protease. Saravanakumar et al. (2010) reported that the medium composition and some physical factors such as the $\mathrm{pH}$, fermentation period and temperature greatly influence the extracellular protease production. $\mathbf{E l}$ Enshasy et al. (2008) emphasized that for the improvement of yield of proteases, the optimization of the production medium and the physical conditions are to be considered to develop an economically feasible technology. Better fermentation conditions will enhance higher production of proteases.

Extracellular protease production in microorganisms is strongly influenced by medium components such as carbon and nitrogen sources (Beg et al., 2002) and metal ions (Varela et al., 1996). Banerjee et al. (1993) reported that a complex medium has been found to be suitable for protease production and they are dependent on the nutritional requirement of the organism under consideration. $A$. nidulans LCJ249 and A. flavus LCJ253 had varied preference toward the carbon sources. A nidulans LCJ249 preferred glucose while A. flavus LCJ253 preferred starch for maximum protease production. There are also reports showing that different carbon sources have different influences on extracellular enzyme production by different strains (Wang and Lee, 1996; Nehra et al., 2002). The present results is in agreement with Srinubabu et al. (2007), Tremacoldi and Carmona (2005) and Chellapandi (2010) who reported glucose as the best carbon sources for improving the production of proteases by Aspergillus flavus, Aspergillus clavatus and Aspergillus terrus. This stimulatory effect of glucose on protease production by glucose indicates that protease production by A. nidulans LCJ249 may not be subject to control by catabolite repression. The stimulatory effect may also due to the fact that glucose is a monosaccharide and is readily available for the metabolism of the fungus for enzyme production. Several researchers have reported about the repression of protease synthesis and its secretion due to glucose in different microorganisms (Tsuchiya and Kimura 1984; Taragano et al., 1997). In contrast to the stimulatory effect of glucose, Sani et al. (1992) reported that starch/complex carbon sources supported the highest fungal growth and enzyme production in Aspergillus and this was evident in the present study. The influence of starch on the production of protease has also been reported by Siala $\boldsymbol{e t}$ al. (2012). The present study is also in agreement with Srinubabu et al. (2007) who reported that starch and glucose will be more suitable and cost-effective carbon source for commercial protease production.

Generally in addition to an energy source and trace elements, a suitable nitrogen source in adequate quantities is essential for the rapid growth of the fungus. In the present study, organic nitrogen substances were suitable for protease production. Accordingly, malt extract enhanced maximum protease production in A. nidulans LCJ249 and peptone in the case of A. flavus LCJ253. Banerjee et al. (1999) reported that malt extract and yeast extract significantly induced the production of protease. In another study, addition of soybean meal in combination with peptone to growth medium has been shown to increase protease production by A. carbonarius (Ire et al., 2011). Peptone contain high amount of peptides. Proteases break down proteins and peptides. Hence, the presence of peptides in the culture medium could have induced production of protease (Siala et al., 2012). Peptones are also known to sustain rapid growth of fungi (Yan $\boldsymbol{e t}$ al., 2012). The present study also revealed that organic nitrogen source showed better protease production than inorganic nitrogen sources. This better production with organic nitrogen sources can be correlated to their capacity to induce protease production. Organic nutrients are also less expensive and supplies the necessary minerals and vitamins required for protease production. The cell growth is also further rapid and efficient when organic nitrogen sources are used, since they decrease the number of components that cells would otherwise have to be synthesized.

The addition of inducers such as casein increases the protease production. In the present study an increase in inducer concentration increased protease activity Protease activity was the maximum at $15 \mathrm{~g} / \mathrm{L}$ and further addition of casein decreased the activity. Similarly, Escobar and Barnett (1993) reported that the enzyme production will decrease if the substrate concentration increases. When the substrate concentration is too high, it may also prohibit the enzyme activity (Dekleva, 1985). Andrade et al. (2002) demonstrated that protease activity was at its maximum when $40 \mathrm{~g} / \mathrm{L}$ of the substrate (casein) was used. The amino acids and peptides in casein may be served as specific inducers for increasing protease production by A. nidulans LCJ249 and A. flavus LCJ253.

Enzyme production is also very much dependant on the $\mathrm{pH}$ of the fermentation medium (Kubackova et al., 1975). pH influences the enzymatic processes and also plays a major role in the transport process of diverse of components across the cell membrane (Sandhya et al., 2005; Paranthaman et al., 2009; Murthy and Naidu, 2010). Neutral $\mathrm{pH}$ helps in the cell growth but acidic and alkaline $\mathrm{pH}$ act as an inhibitor to the cell growth and this will affect the enzyme production by the cells. Chakrabarti et al. (2000) proved that Aspergillus terreus managed to produce protease between $\mathrm{pH} 5.5$ and 9.5. In the present study, protease production by A. nidulans LCJ249 and A. flavus LCJ253 was influenced by the initial $\mathrm{pH}$ of the medium. The best protease production was observed when the initial $\mathrm{pH}$ was 7 in A. nidulans LCJ249 and A. flavus LCJ253. Similarly, Mellon and Cotty (1996) reported that $\mathrm{pH} 7.5$ was optimum for maximum protease production by A. flavus. Ire et al. (2011) reported that $\mathrm{pH} 6.0$ as the best initial $\mathrm{pH}$ for the production of protease by A. carbonarius. The influence of $\mathrm{pH}$ on the protease production could be due to its effect on the stability or conformation of the plasma membrane which indirectly affects the membrane bound ribosomes involved in the synthesis of protease (Razak $\boldsymbol{e t}$ al., 1997).

The initial inoculum size affects the growth and in turn affects the metabolite production. In the present investigation, the effect of inoculum size on the production of protease by A. nidulans LCJ249 and A. flavus LCJ253 was studied. Raimbault and Alazard (1980) reported that the decline in enzyme production with high inoculum size was related to the production of high biomass which is responsible for the reduction of the enzyme. Higher inoculum sizes have been found to negatively affect protease production in the study. This is in agreement with previous observations that reported that higher inoculum sizes need not necessarily give higher protease yield or cell growth. Higher inoculum sizes could result in the depletion of oxygen and nutrients in the culture media.

The production of protease under shaking condition was better when compared to static cultures. In the fermentation process using an aerobic culture, the oxygen affects the production of enzymes due to the changes in the metabolic pathway and metabolic fluxes (Calik et al., 1998). Ducros et al. (2009) suggested that the respiration rate of the aerobic culture is dependent on the dissolved oxygen. This is due to physiological alteration in cell metabolism (Hwang et al., 1991). In A. flavus LCJ253, shaking condition favoured protease production which is could be due to lower availability of dissolved oxygen with low mixing rates (Potumarthi et al., 2007). These results were consistent with the observations of Beg et al. (2002) for Bacillus mojavensis where shaking was required to stimulate protease production.

Thus protease production by A. nidulans LCJ249 and A. flavus LCJ253 under submerged fermentation were effectively enhanced by optimizing the physical and essential nutritional parameters by the conventional one factor at a time method and scaling up of the protease production was also carried out.

\section{CONCLUSION}

In this study, optimization of the culture media for maximizing protease production by submerged fermentation was carried out. The selection of a suitable production medium, carbon, nitrogen, inducer, $\mathrm{pH}$, inoculum size, incubation time for protease production by submerged fermentation was carried out in a way to induce higher degree of protease production and also to minimize the operating cost. The modified medium composition and cultural conditions showed enhanced protease production compared to the original medium conditions. The modified conditions were also implemented under large scale for the production of extracellular fungal proteases.

Acknowledgments: The authors are grateful to the Management, Loyola College, Chennai for providing necessary facilities and encouragement. 


\section{REFERENCES}

ANDRADE, V.S., SARUBHO, L.A., FUKUSHIMA, K., MIYAJI, M., NISHIMURA, K., MARIA, D.E., CAMPOS-TAKAKI, G.L. 2002. Production of extracellular protease by Mucor circinelloides using D-glucose as carbon source/substrate. Brazilian Journal of Microbiology, 33(9), 106110.http://dx.doi.org/10.1590/S1517-83822002000200002

ANWAR, A., SALEEMUDDIN, M. 1998. Alkaline proteases: a review. Bioresource Technology, 6, 175-183.http://dx.doi.org/10.1016/s09608524(97)00182-x

ASOODEH, A., MOUSSA ABADI, H.M. 2012. Purification and characterization of a thermostable neuthrophilic metalloprotease from Pseudomonas sp. DR89. Iranian Journal of Biotechnology, 10, 120-128. BANERJEE, R., AGNIHOTRI, R., BHATTACHARYYA, B.C. (1993) Purification of alkaline protease of Rhizopus oryzae by foam fractionation. Bioprocess Engineering, 9(6), 245-248. http://dx.doi.org/10.1007/bf01061529 BANERJEE, U.C., SANI, R.K., AZMI, W., SONI, R. 1999. Thermostable alkaline protease from Bacillus brevis and its characterization as a laundry detergent additive. Process Biochemistry, 35(1-2), 213-219. http://dx.doi.org/10.1016/s0032-9592(99)00053-9

BEG, Q.K., SAXENA, R.K., GUPTA, R. 2002. De-repression and subsequent induction of protease synthesis by Bacillus mojavensis under fed-batch operations. Process Biochemistry, 37(10), 1103-1109. http://dx.doi.org/10.1016/s0032-9592(01)00320-x

CALIK, P., CALIK, G., OZDAMAR, T.H. 1998. Oxygen transfer effects in serine alkaline protease fermentation by Bacillus licheniformis: Use of citric acid as the carbon source. Enzyme and Microbial Technology, 23(7-8), 451-461. http://dx.doi.org/10.1016/s0141-0229(98)00069-6

CHAKRABARTI, S.K., MATSUMURA, N., RANU, R.S. 2000. Purification and characterization of an extracellular alkaline serine protease from A. terreus. Curr Microbiology, 40, 239-244

CHARLES, P., DEVANATHAN, V., ANBU, P., PONNUSWAMY, M.N., KALAICHELVAN, P.T., HUR, B.K. 2008. Purification, characterization and crystallization of an extracellular alkaline protease from Aspergillus nidulans HA-10. Journal of Basic Microbiology, 48(5), 347-352. http://dx.doi.org/10.1002/jobm.200800043

CHELLAPANDI, P. 2010. Production and Preliminary Characterization of Alkaline Protease from Aspergillus flavus and Aspergillus terreus. The $\begin{array}{llll}\text { Electronic Journal of Chemistry, } & 7(2), & 479-482 .\end{array}$ http://dx.doi.org/10.1155/2010/502583

DEKLEVA, M.L., TITUS, J.A., STROHL, W.R. 1985. Nutrient effects on anthracycline production by Streptomyces peucetius in a defined medium Canadian Journal of Microbiology, 31(3), 287-294. http://dx.doi.org/10.1139/m85-053

DUCROS, E., FERRARI, M., PELLEGRINO, M., RASPANTI, C., BOGNI, C. 2009. Effect of aeration and agitation on the protease production by Staphylococcus aureus mutant RC128 in a stirred tank bioreactor. Bioprocess Biosystem Engineering, 32 (1), 143-148. http://dx.doi.org/10.1007/s00449-0080233-5

EL ENSHASY, H., ABUOUL-I., ENEIN, A, HELMY, S., EL AZALY, Y. 2008. Optimization of the industrial production of alkaline protease by Bacillus licheniformis in different production scales. Australian Journal of Basic Applied Sciences, 2(3), 583-593

ESCOBAR, J., BARNETT, S.M. 1993. Effect of agitation speed on the synthesis of Mucor miehei acid protease. Enzyme and Microbial Technology, 15(12), 1009-1013. http://dx.doi.org/10.1016/0141-0229(93)90047-6

GENCKAL, H., TARI, C. 2006. Alkaline protease production from alkalophilic Bacillus sp. isolated from natural habitats. Enzyme and Microbial Technology, 39(4), 703-710. http://dx.doi.org/10.1016/j.enzmictec.2005.12.004

GRADISAR, H., FRIEDRICH, J., KRIZAJ, I., JERALA, R. 2005. Similarities and specificities of fungal keratinolytic proteases: comparison of keratinases of Paecilomyces marquandii and Doratomyces microsporus to some known proteases. Applied and Environmental Microbiology, 71(7), 3420-3426. http://dx.doi.org/10.1128/aem.71.7.3420-3426.2005

HWANG, S.T., WACHTER, C., SCHATZ, G. 1991. Protein import into the yeast mitochondrial matrix- A new translocation intermediate between the two mitochondrial membranes. The Journal of Biological Chemistry, 266, $21083-$ 21089.

IKRAM-UL-HAQ., MUKHTAR, H., UMBER, H. 2006. Production of Protease by Penicillium chrysogenum through Optimization of Environmental Conditions. Journal of Agriculture, Forestry and the Social Sciences, 2(1), 23-25. IRE, F.S., OKOLO, B.N., MONEKE, A.N., ODIBO, F.J.C. 2011. Influence of cultivation conditions on the production of a protease from Aspergillus carbonarius using submerged fermentation. African Journal of Food Science, 5(6), 353-365.

KUBACKOVA, M., KARACSONYI, S., VARADI, J. 1975. Studies on xylanase from Basidiomycetes. Folia Microbiologica, 20(1), 29-37. http://dx.doi.org/10.1007/bf02877083

KUMARA, C.G., TIWARIB, M.P., JANYA, K.D. 1999. Novel alkaline serine proteases from alkalophilic Bacillus spp.: purification and some properties.
Process Biochemistry, 34(5), 441-449. http://dx.doi.org/10.1016/s00329592(98)00110-1

LEKHA, P.K., LONSANE, B.K. 1994. Comparative titres, location and properties of tannin acyl hydrolase produced by Aspergillus niger PKL104 in solid-state, liquid surface and submerged fermentation. Process Biochemistry, 29(6), 497-503. http://dx.doi.org/10.1016/0032-9592(94)85019-4

LOWRY, O.H., ROSEBROUGH, N.J., FARR, A.L., RANDALL, R.J. 1951. Protein measurement with Folin Phenol Reagent. The Journal of Biological Chemistry, 193, 265-275.

MELLON, J.E., COTTY, P.J. 1996. Purification and partial characterization of an elastinolytic proteinase from Aspergillus flavus culture filtrates. Applied Microbiology and Biotechnology, 46 (2), 138-142. http://dx.doi.org/10.1007/s002530050795

MURTHY, P.S., NAIDU, M.M. 2010. Protease production by Aspergillus oryzae in solid state fermentation utilizing coffee by products. World Applied Sciences Journal, 8, 199-205.

NAMASIVAYAM, S.K.R., SIVASUBRAMANIAN, S., KUMAR, G. 2010 Influence of media on protease production by Beauveria bassiana ( Bals.) Vuil. and stability towards commercially available detergents, surfactants and enzyme inhibitors. International Journal of Biological Technology, 1(1), 78-83.

NEHRA, K.S., DHILLON, S., CHAUDHARY, K., SINGH, K. 2002. Production of alkaline protease by Aspergillus species under submerged and solid state fermentation. Indian Journal of Microbiology, 42, 43-47.

PARANTHAMAN, R., ALAGUSUNDARAM, K., INDUMATHI. 2009 Production of protease from rice mill wastes by Aspergillus niger in Solid State Fermentation. World Journal of Agricultural Sciences, 5(3), 308-312.

POTUMARTHI, R., SUBHAKAR, C., JETTY, A. 2007. Alkaline protease production by submerged fermentation in stirred tank reactor using Bacillus licheniformis NCIM-2042: Effect of aeration and agitation regimes. Biochemical Engineering Journal, 34(2), 185-192. http://dx.doi.org/10.1016/j.bej.2006.12.003

RAIMBAULT, M., ALAZARD, D. 1980. Culture method to study fungal growth in solid fermentation. Electron Journal of Applied Microbiology, 9(3), 199-209. http://dx.doi.org/10.1007/bf00504486

RANI, R.M., PRASAD, N.N., SAMBASIVARAO, K.R.S. 2012. Optimization of Cultural Conditions for the Production of Alkaline Protease from a Mutant Aspergillus Flavus AS2. Asian Journal of Experimental Biological Sciences, 3(3), 565-576

RAO, M.B., TANKSALE, A.M., GHATGE MS, DESHPANDE, V.V. 1998 Molecular and biotechnological aspects of microbial proteases. Microbiology and Molecular Biology Reviews, 62, 597-635.

RAZAK, C.N.A., TANG, S.W., BASRI, M., SALLEH, A. 1997. Preliminary study on the production of extracellular protease from a newly isolated Bacillus sp. (no 1) and the physical factors affecting its production. Pertanika Journal of Science and Technology, 5,169-177.

SANDHYA, C., SUMANTHA, A., SZAKACS, G., PANDEY, A. 2005. Comparative evaluation of neutral protease production by Aspergillus oryzae in submerged and solid state fermentation. Process Biochemistry, 40(8), 26892694. http://dx.doi.org/10.1016/j.procbio.2004.12.001

SANI, A., AWE, F.A., AKINYANJU, J.A. 1992. Amylase synthesis in Aspergillus flavus and Aspergillus niger grown on cassava peel. Journal of Industrial Microbiology, 10, 55-59. http://dx.doi.org/10.1007/BF01583634

SARAVANAKUMAR, K., THIYAGARAJAN, A., KAVIYARASAN, V. 2010. Optimization of medium constituents for the production of extracellular alkaline Protease by Aspergillus fischeri using response surface experimental design. Journal of Biosciences Resource, 1(3), 118-129.

SIALA, R., FRIKHA, F., MHAMDI, S., NASRI. M., SELLAMI KAMOUN, A. 2012. Optimization of Acid Protease Production by Aspergillus niger I1 on Shrimp Peptone Using Statistical Experimental Design. The Scientific World Journal, 2012, 1-11. http://dx.doi.org/10.1100/2012/564932

SON, E.S., KIM, J.I.I. 2002. Purification and characterization of caseinolytic extracellular protease from Bacillus amyloliquefaciens S94. Journal of Microbiology, 40(1), 26-32

SRINUBABU, G., LOKESWARI, N., JAYARAJU, K. 2007. Screening of nutritional parameters for the production of protease from Aspergillus oryzae. EJ Chemistry, 4(2), 208-215. http://dx.doi.org/10.1155/2007/915432

TARAGANO, V., SANCHEZ, V.E., PILOSOF, A.M.R. 1997. Combined effect of water activity depression and glucose addition on pectinases and protease production by Aspergillus niger. Biotechnology Letters, 19, 233-236.

TREMACOLDI, C.R., CARMONA, E.C. 2005. Production of extracellula alkaline proteases by Aspergillus clavatus. World Journal of Microbiology and Biotechnology, 21, 169-172. http://dx.doi.org/10.1007/s11274-004-2724-0

TSUCHIYA, K., KIMURA, T. 1984. Decrease of protease activity by addition of glucose to the culture of Cephalosporium sp. Journal of Fermentation Technology, 62, 35-39.

TSUCHIYA, K., NAKAMURA, Y., SAKASHITA, H., KIMURA, T. 1992 Purification and characterization of a thermostable alkaline protease from alkalophilic Thermoactinomyces sp. HS682. Bioscience Biotechnology and Biochemistry, 56(2), 246-250. http://dx.doi.org/10.1271/bbb.56.246 
VARELA, H., FERRARI, M.D., BELOBRADJIC, L., WEYRAUCH, R., LOPERENA, L. 1996. Effect of medium composition on the production by a new Bacillus subtilis isolate of protease with promising unhairing activity. World Journal of Microbiology and Biotechnology, 12(6), 643645.http://dx.doi.org/10.1007/bf00327730

WANG, Y., LEE, M. 1996. Influence of culture and nutritional condition on the production of protease from Thermophilic strain Aspergillus species NTIJ-FC671. Journal of the Chinese Agricultural Chemical Society, 34, 732-742.

WU, L.C., HANG, Y.D. 2000. Acid protease production from Neosartorya fischeri. Food Science and Technology, 33(1), 4447.http://dx.doi.org/10.1006/fstl.1999.0608

YAN, S., LIANG, Y., ZHANG, J., LIU, C.M. 2012. Aspergillus flavus grown in peptone as the carbon source exhibits spore density-and peptone concentrationdependent aflatoxin biosynthesis. BMC microbiology, 12 (1), 106106 http://dx.doi.org/10.1186/1471-2180-12-106 